\title{
'Silent' priming of translation-dependent LTP by $\beta$-adrenergic receptors involves phosphorylation and recruitment of AMPA receptors
}

\author{
Gustavo Tenorio, ${ }^{1,6}$ Steven A. Connor, ${ }^{2,6}$ Diane Guévremont, ${ }^{3}$ Wickliffe C. Abraham, ${ }^{4}$ \\ Joanna Williams, ${ }^{3}$ Thomas J. O'Dell, ${ }^{5}$ and Peter V. Nguyen ${ }^{1,2,7}$ \\ ${ }^{1}$ Department of Physiology, University of Alberta School of Medicine, Edmonton, Alberta, T6G 2H7, Canada; ${ }^{2}$ Centre for Neuroscience, \\ University of Alberta School of Medicine, Edmonton, Alberta, T6G 2H7, Canada; ${ }^{3}$ Department of Anatomy and Structural Biology, \\ Brain Health and Repair Research Centre, University of Otago, Dunedin 9054, New Zealand; ${ }^{4}$ Department of Psychology, Brain Health \\ and Repair Research Centre, University of Otago, Dunedin 9054, New Zealand; ${ }^{5}$ Department of Physiology, David Geffen School of \\ Medicine, Center for the Health Sciences, University of California, Los Angeles, California 90095-1751, USA
}

\begin{abstract}
The capacity for long-term changes in synaptic efficacy can be altered by prior synaptic activity, a process known as "metaplasticity." Activation of receptors for modulatory neurotransmitters can trigger downstream signaling cascades that persist beyond initial receptor activation and may thus have metaplastic effects. Because activation of $\beta$-adrenergic receptors ( $\beta$-ARs) strongly enhances the induction of long-term potentiation (LTP) in the hippocampal CAl region, we examined whether activation of these receptors also had metaplastic effects on LTP induction. Our results show that activation of $\beta$-ARs induces a protein synthesis-dependent form of metaplasticity that primes the future induction of late-phase LTP by a subthreshold stimulus. $\beta$-AR activation also induced a long-lasting increase in phosphorylation of $\alpha$-amino-3-hydroxy-5-methyl-4-isoxazolepropionic acid receptor (AMPAR) GluAl subunits at a protein kinase A (PKA) site (S845) and transiently activated extracellular signal-regulated kinase (ERK). Consistent with this, inhibitors of PKA and ERK blocked the metaplastic effects of $\beta$-AR activation. $\beta$-AR activation also induced a prolonged, translation-dependent increase in cell surface levels of GluAl subunit-containing AMPA receptors. Our results indicate that $\beta$ ARs can modulate hippocampal synaptic plasticity by priming synapses for the future induction of late-phase LTP through up-regulation of translational processes, one consequence of which is the trafficking of AMPARs to the cell surface.
\end{abstract}

Long-term potentiation (LTP), an activity-dependent increase in synaptic transmission, is considered the leading cellular mechanism underpinning learning and memory (Bliss and Lømo 1973; Bliss and Collingridge 1993). Interestingly, the previous history of synaptic activity can prime future changes in synaptic strength through a process known as "metaplasticity" (Abraham and Bear 1996; Abraham 2008; Abraham and Williams 2008). Metaplasticity, by expanding the temporal window for formation of associative memories, may provide the necessary mechanisms for binding temporally separated events. For example, prior activation of ryanodine receptors facilitates the induction and persistence of homosynaptic and heterosynaptic LTP elicited by a subthreshold stimulation protocol applied $30 \mathrm{~min}$ later (Mellentin et al. 2007; Sajikumar et al. 2009). Thus, prior cellular activity can alter the threshold for the induction of LTP in a cellwide manner and extend the time periods typically associated with synaptic integration.

Synaptic activity is subject to modulation through activation of $G$ protein-coupled receptors, which can influence synaptic responses on timescales that extend well beyond the secondsminutes of initial receptor activation (O'Connor et al. 1994;

\footnotetext{
${ }^{6}$ These authors contributed equally to this work.

${ }^{7}$ Corresponding author.

E-mail peter.nguyen@ualberta.ca; fax (780) $492-8915$.

Article is online at http://www.learnmem.org/cgi/doi/10.1101//m.1974510.
}

Cohen et al, 1999). Metaplastic processes can be regulated through neuromodulators by lowering the threshold for induction of LTP or by extending its maintenance. Previous studies have demonstrated that $\beta$-adrenergic receptor ( $\beta$-AR) activation reduces the threshold for the induction of protein synthesisdependent LTP in the hippocampus, a brain structure critically involved in memory formation (Straube et al. 2003; Gelinas and Nguyen 2005). LTP induction can also be regulated by phosphorylation and insertion of postsynaptic glutamate receptors (GluRs). Norepinephrine, a stress hormone released in response to emotional and arousing stimuli, induced a $\beta$-AR-dependent phosphorylation of GluA1 (also termed GluR1), in mouse hippocampus that facilitated the subsequent synaptic delivery of GluA1. GluA1 phosphorylation correlated with lowered thresholds for both memory formation and LTP induction (Hu et al. 2007). Similarly, PKA-dependent phosphorylation and insertion of GluA1 are increased following chemical potentiation with forskolin (a cAMP agonist), and correlate with the degree of LTP expressed (Oh et al. 2006; Man et al. 2007). Activation of $\beta$-ARs, by increasing levels of cAMP (O'Dell et al. 2010), can also engage intracellular signaling cascades involved in translation regulation (Gelinas et al. 2007). In previous studies, we have shown that activation of translational mechanisms by Group 1 metabotropic glutamate receptors leads to priming of local translationdependent LTP (Raymond et al. 2000). As $\beta$-ARs couple to translation regulation mechanisms, we tested whether activation of 
$\beta$-ARs engage similar metaplasticity mechanisms for priming LTP through regulation of GluRs and protein synthesis.

We report that activation of $\beta$-ARs with the $\beta$-AR agonist isoproterenol (ISO) facilitates the subsequent induction of LTP by a subthreshold stimulation protocol. Blocking $\beta$-ARs with propranolol during ISO application prevented the subsequent induction of LTP. Additionally, ISO significantly increased GluA1 phosphorylation at serine 845 (S845), as well as increasing GluA1 surface expression. Inhibition of cAMP-dependent protein kinase (PKA), and extracellular signal-regulated kinase (ERK) similarly blocked metaplasticity, as did protein synthesis inhibition. Our findings thus provide evidence that $\beta$-ARs prime metaplastic mechanisms that support the induction of protein synthesis-dependent LTP.

\section{Results}

Activation of $\beta$-ARs primes the future induction of LTP Activation of $\beta$-ARs in the CA1 region of mouse hippocampal slices enhances the induction of LTP by stimulation protocols that are normally subthreshold for generating persistent enhancement of extracellular field EPSPs (fEPSPs) (Thomas et al. 1996; Katsuki et al. 1997). We sought to determine whether $\beta$-AR activation could engage metaplastic mechanisms that enhance the future induction of LTP. Application of a $\beta$-AR agonist, ISO $(1 \mu \mathrm{M})$, to area CA1 of hippocampal slices for 15 min caused a transient facilitation of baseline synaptic responses that rapidly decayed to control levels (Fig. 1B; fEPSPs were 103\% $\pm 4 \%$ of baseline slopes 60 min after ISO application). Brief high-frequency stimulation (HFS; $1 \times 100 \mathrm{~Hz}, 1 \mathrm{sec}$ ) applied after $80 \mathrm{~min}$ of baseline stimulation induced decremental LTP which returned to baseline in $<2 \mathrm{~h}$ (104\% $\pm 6 \% 120$ min after HFS). However, the 15-min ISO application facilitated the induction and persistence of LTP when HFS was delivered $1 \mathrm{~h}$ after washout (Fig. 1A; 144\% $\pm 6 \% 120$ min after HFS; $P<0.01$ compared with $100 \mathrm{~Hz}$ alone). These results suggest that prior $\beta$-AR receptor activation can facilitate L-LTP induction up to $1 \mathrm{~h}$ after $\beta$-AR stimulation.

To determine the duration of the temporal window for $\beta$-AR-mediated metaplastic effects, we extended the length of time between ISO and HFS to $2 \mathrm{~h}$. Under these conditions, LTP was not induced (Fig. 1B; fEPSPs were 102\% $\pm 5 \% 120 \mathrm{~min}$ after HFS). Thus, $\beta$-AR activation enhances the ability of future stimuli
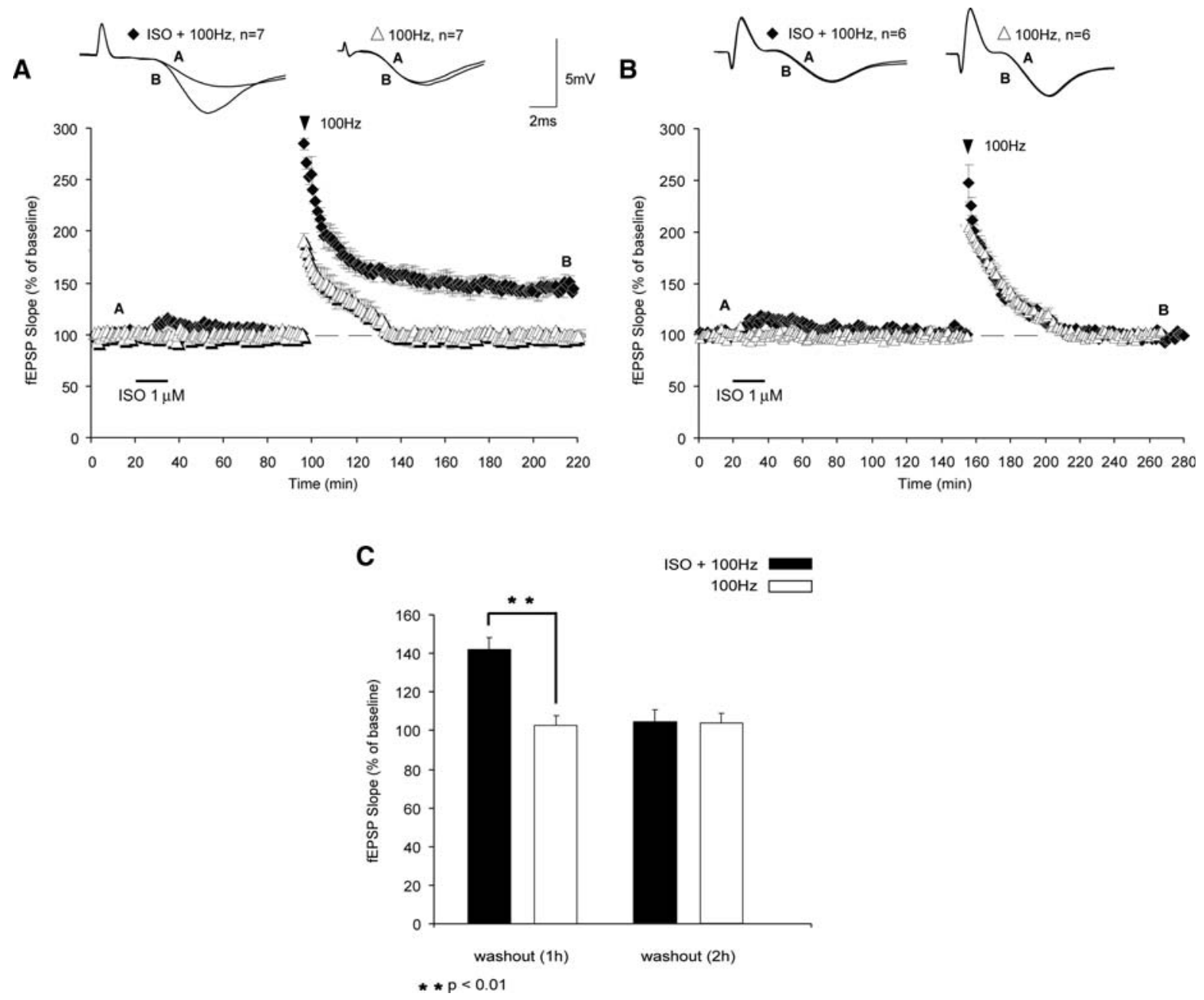

Figure 1. $\beta$-ARs activation induces metaplasticity by reducing the threshold for future LTP induction. (A) ISO application facilitates the induction of LTP (filled diamonds) by subthreshold (HFS: $1 \times 100 \mathrm{~Hz}, 1 \mathrm{sec}$ ) stimulation $1 \mathrm{~h}$ after washout, whereas HFS stimulation alone results in LTP that decays to baseline in $<2 \mathrm{~h}$ (open triangles). (B) The metaplastic effect of ISO is temporally limited, as extending the interval between ISO and HFS to $2 \mathrm{~h}$ prevented the metaplastic facilitation of LTP. (C) Summary histogram comparing fEPSP slopes obtained $120 \mathrm{~min}$ after HFS. Sample traces were taken 10 min after commencement of baseline recordings and 120 min after HFS. Results in $C$ represent means \pm SEM; $* * P<0.01$. 
to induce LTP in a temporally restricted $(<2 \mathrm{~h})$ fashion, without significantly altering baseline responses. These data suggest that $\beta$-ARs can regulate the modifiability of synaptic plasticity for at least $1 \mathrm{~h}$ after their activation, and these effects result in enhanced synaptic efficacy in response to stimuli that are normally subthreshold for inducing LTP.

\section{Metaplasticity induced by ISO application requires $\beta$-adrenergic and NMDA receptors}

Noradrenaline (NA) has been shown to have a crucial role in some forms of synaptic plasticity (Gelinas and Nguyen 2005) and in the formation and retrieval of memories (Berridge and Waterhouse 2003). NA alters synaptic plasticity through activation of $\beta$-ARs, an effect mediated primarily through the $\beta 1$-AR subtype (Winder et al. 1999). Induction of LTP by HFS applied $1 \mathrm{~h}$ after ISO application was inhibited by coapplication of a $\beta$-adrenergic antagonist, propranolol $(50 \mu \mathrm{M})$, overlapping with ISO (Fig. 2A; fEPSPs were $98 \% \pm 8 \%$ of baseline levels 120 min after HFS; $P<$ 0.01 compared with controls). Shifting application of propranolol to $40 \mathrm{~min}$ after ISO application, however, had no effect on the induction of LTP (Fig. 2B; fEPSPs were potentiated to $143 \% \pm 3 \%$ 120 min after HFS; $P>0.05$ ). This indicates that the long-lasting enhancement of LTP induction produced by $\beta$-AR activation is not due to slow washout of ISO from the slice. Instead, our results suggest that only a transient activation of $\beta$-ARs is needed to engage the metaplastic processes that enable future LTP induction.

Induction of standard LTP in CA1 requires activation of $\mathrm{N}$-methyl-D-aspartate receptors (NMDARs) (Collingridge et al. 1983; Morris et al. 1990). To determine whether NMDARs are required for induction of the primed LTP, or whether $\beta$-AR priming promotes subsequent induction of an NMDAR-independent form of LTP, we applied the NMDA receptor antagonist 2-amino-5-phosphonovaleric acid, APV $(50 \mu \mathrm{M})$, overlapping with HFS after prior application of ISO. The induction of LTP primed by prior $\beta$-AR stimulation was blocked when APV was paired with HFS (Fig. 3A; fEPSPs were 105\% $\pm 3 \%$ of baseline levels 120 min after HFS; $P<0.01$ compared with controls). Thus, metaplasticity engaged by prior $\beta$-AR activation facilitates the NMDAR-dependent form of LTP

\section{$\beta$-AR-primed LTP is immune to depotentiation (DPT)}

DPT is the activity-induced reversal of LTP, which may play a role in maintaining synaptic homeostasis (Staubli and Lynch 1990; Fujii et al. 1991; Huang et al. 1999). Low-frequency stimulation
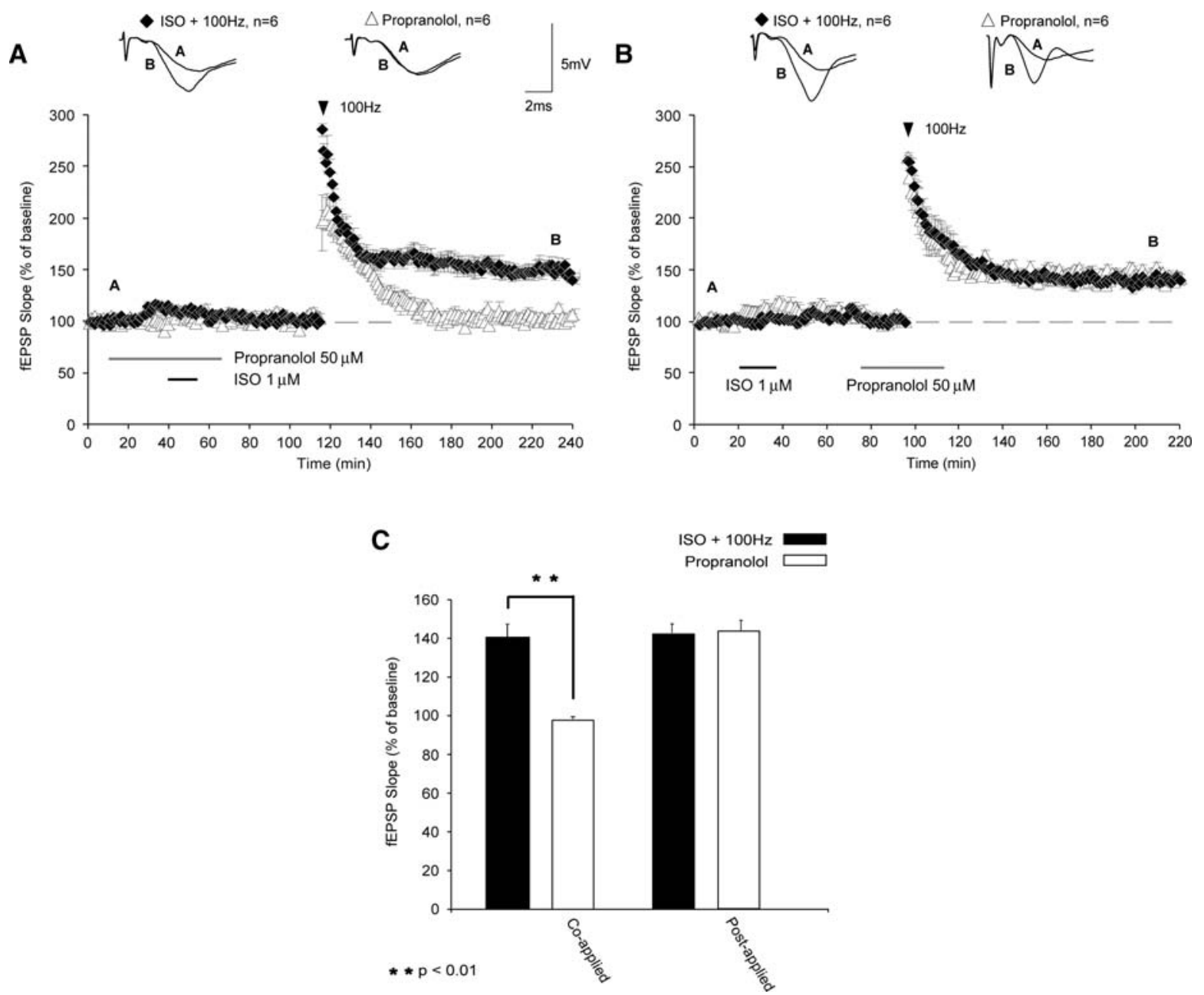

Figure 2. $\beta$-ARs are required for priming of LTP. (A) Application of the $\beta$-AR antagonist propranolol during $\beta$-AR activation inhibited metaplasticity (filled triangles). (B) Shifting propranolol application to overlap with HFS did not impair LTP (black diamonds). (C) Summary histogram comparing fEPSP slopes obtained $120 \mathrm{~min}$ after HFS. Sample traces were taken $10 \mathrm{~min}$ after commencement of baseline recordings and 120 min after HFS. Results in C represent means $\pm \mathrm{SEM} ; * * P<0.01$. 


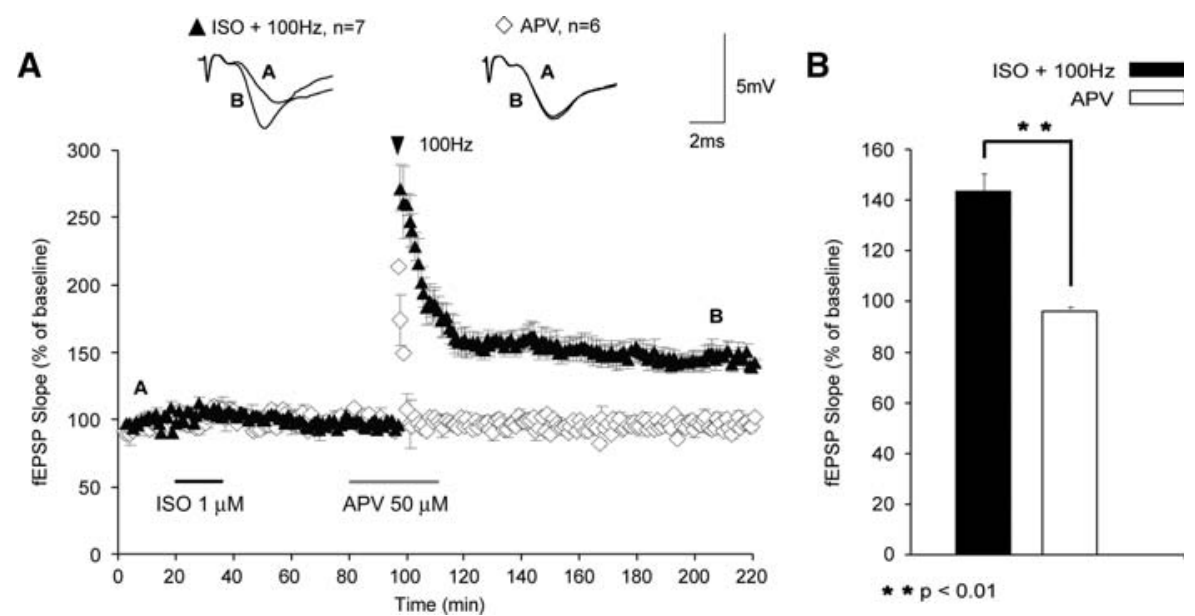

Figure 3. NMDAR activation is required for the induction of $\beta$-adrenergic receptor-primed LTP. (A) When the NMDAR antagonist APV was applied during HFS and after prior application of ISO, the metaplastic facilitation of LTP was blocked (open diamonds). Control slices not exposed to APV (black triangles) displayed significantly enhanced expression of LTP compared with APV-treated slices. (B) Summary histogram comparing fEPSP slopes $120 \mathrm{~min}$ after HFS. Sample traces were taken $10 \mathrm{~min}$ after commencement of baseline recordings and 120 min after HFS. Results in $B$ represent means \pm SEM; ${ }^{* * P}<0.01$.

(LFS; $5 \mathrm{~Hz}, 3 \mathrm{~min}$ ) can induce DPT (O’Dell and Kandel 1994) provided that the LTP expressed does not require translation, as protein synthesis confers immunity to DPT (Woo and Nguyen 2003). To determine whether this form of $\beta$-AR-primed LTP was immune to DPT, we applied a depotentiating stimulus protocol ( $5 \mathrm{~Hz}, 3 \mathrm{~min}) 10 \mathrm{~min}$ following the induction of LTP. LTP induced $1 \mathrm{~h}$ after ISO application was not susceptible to DPT, as synaptic potentials returned to pre-DPT levels of increased potentiation observed when no depotentiating stimulus was applied (Fig. 4A; fEPSPs were potentiated to $149 \% \pm 3 \% 120 \mathrm{~min}$ after DPT; $P<$ 0.01 compared with controls). This result suggests that $\beta$-AR-priming of LTP confers immunity to DPT, perhaps by engaging translation regulation mechanisms that prevent the erasure of previously established LTP. after HFS; $P<0.05$ compared with controls). Shifting application of ANI to overlap with HFS had no effect on the induction of LTP (Fig. 5B; fEPSPs were potentiated to $151 \% \pm 8 \% 120 \mathrm{~min}$ after HFS). These results suggest that $\beta$-AR activation alone is sufficient for inducing the translation that is necessary for subsequent induction of protein synthesisdependent LTP. The weak HFS used in this study does not by itself initiate the critical protein synthesis, even after priming, as ANI failed to block the metaplastic effects of $\beta$-AR activation when applied during HFS.

The validity of ANI as a translational inhibitor has recently been questioned due to the possibility of negative side effects that are independent of translational inhibition (Routtenberg and Rekart 2005; but see Alberini 2008). To reconcile this issue, we used a second inhibitor of translation, emetine (EME, $20 \mu \mathrm{M}$ ), which targets translational mechanisms separate from those affected by ANI. Similar to our results with ANI, we found that when EME was applied during $\beta$-AR stimulation, subsequent LTP was blocked (Fig. 5D; fEPSPs were $100 \% \pm 6 \%$ of baseline levels 120 min after HFS; $P<0.01$ compared with controls). An analysis of variance (ANOVA) comparing fEPSPs $120 \mathrm{~min}$ after ISO followed by HFS with ISO coapplied with either ANI or EME, followed by HFS demonstrated significant differences between groups $\left(F_{(2,15)}=23.404 ; P<0.01\right)$. Subsequent Tukey-Kramer post-hoc tests revealed that both ANI and EME significantly inhibited LTP $(P<0.05)$. Furthermore, the ANI and EME groups did not significantly differ from each other in their impairment of LTP $(P>0.05)$. Taken together, these data indicate that priming of LTP by $\beta$-AR activation is critically dependent upon protein synthesis, and that the disruption of metaplasticity is not due to nonspecific side effects of translation inhibitors.

\section{Protein synthesis is required for $\beta$-AR-dependent metaplasticity} LTP and long-lasting forms of memory share a similar requirement for protein synthesis. Previously, we have shown that $\beta$-AR activation facilitates the generation of translation-dependent LTP, which is immune to reversal by depotentiating stimuli (Gelinas and Nguyen 2005). As the maintenance of LTP is critically dependent upon de novo protein synthesis (Frey et al. 1988; Nguyen and Kandel 1996; Kandel 2001), we hypothesized that translation is required for the metaplastic enhancement of LTP triggered by $\beta$-ARs.

To address this question, we used the translational inhibitor anisomycin (ANI) at a concentration that inhibits $>80 \%$ of protein synthesis $(40 \mu \mathrm{M}$; Frey et al. 1988). When ANI was coapplied with ISO ( $1 \mathrm{~h}$ prior to HFS), LTP was no longer induced (Fig. 5A; fEPSPs were $101 \% \pm 3 \%$ of baseline levels $120 \mathrm{~min}$

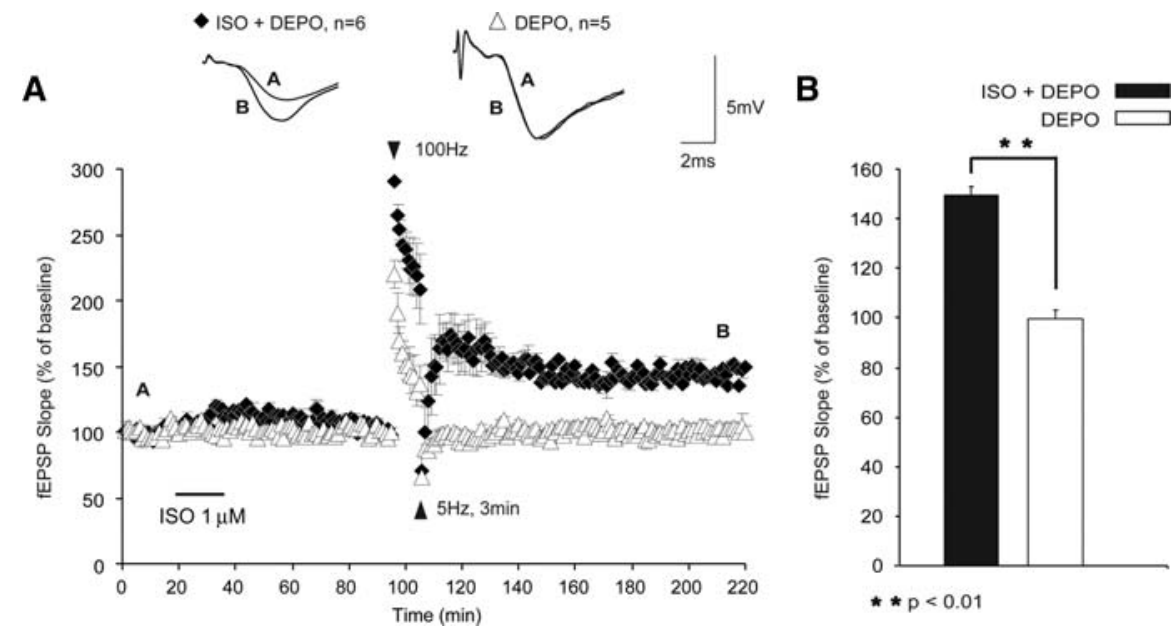

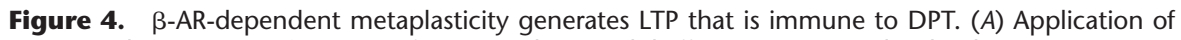
DPT stimuli ( $5 \mathrm{~Hz}, 3 \mathrm{~min}) 10 \mathrm{~min}$ after LTP induction did affect potentiation levels when $\beta$-AR are previously activated (black diamonds). Note gradual recovery of fEPSPs to potentiated levels. (B) Summary histogram comparing fEPSP slopes 120 min after HFS. Sample traces were taken 10 min after commencement of baseline recordings and $120 \mathrm{~min}$ after HFS stimulation. Results in $B$ represent means \pm SEM; $* * P<0.01$. 

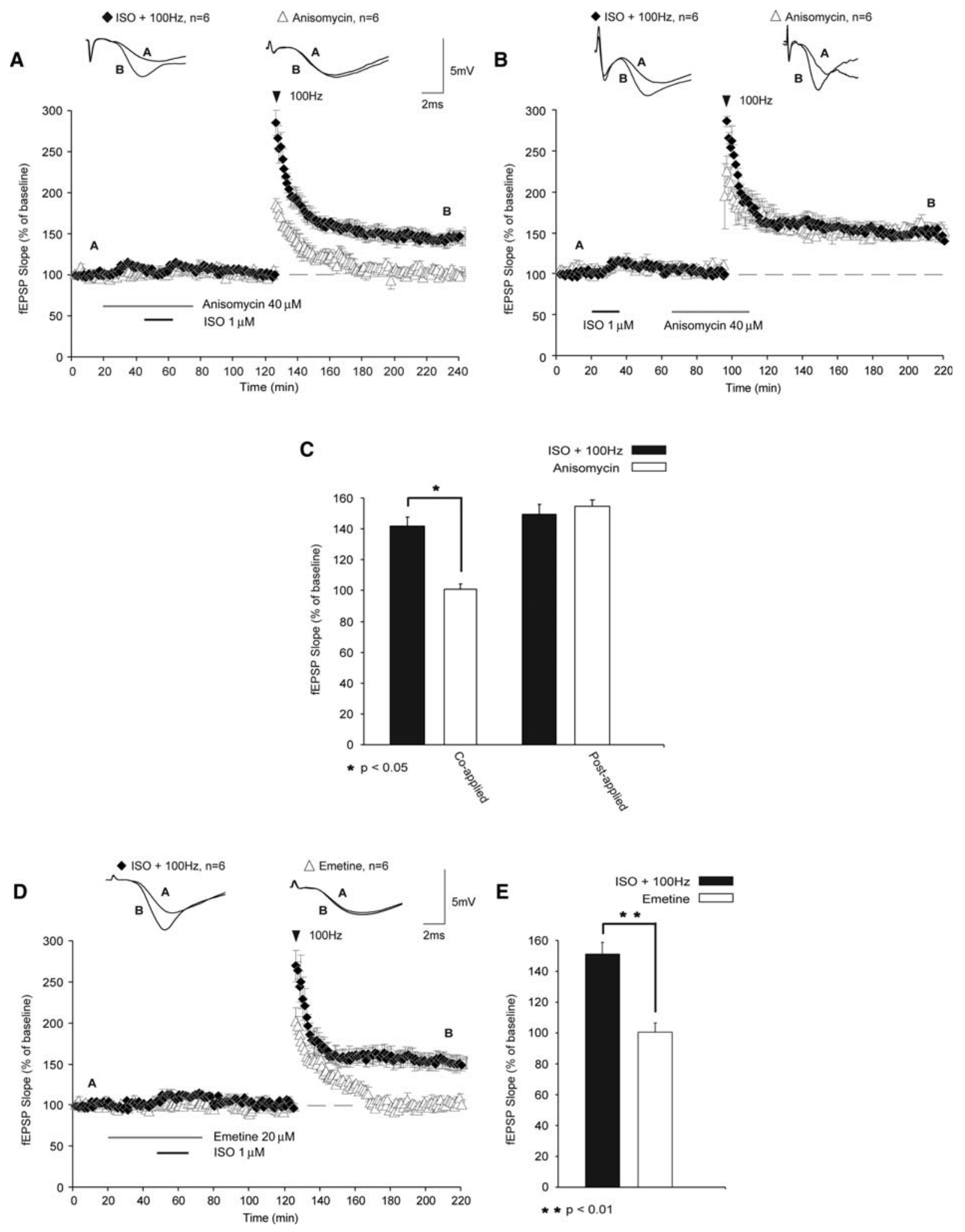

Figure 5. Translation regulation required for metaplasticity is engaged specifically during $\beta$-AR stimulation. (A) Coapplication of ANI with ISO prevented the metaplastic facilitation of LTP (open triangles) when compared with controls not exposed to ANI (black diamonds). (B) Shifting the application of ANI to overlap with HFS (black diamonds) did not impair the metaplastic enhancement of LTP by prior $\beta$-AR activation. These results suggest that translation regulation critical for metaplasticity takes place during $\beta$-AR stimulation but not during subsequent HFS. (C) Comparisons of fEPSP slopes of these experiments are shown in this summary histogram. $(D)$ A second translation inhibitor, EME similarly prevented the expression of metaplasticity when applied during application of ISO (black diamonds). (E) Summary histogram comparing fEPSP slopes 120 min after HFS. Sample traces were taken 10 min after commencement of baseline recordings and $120 \mathrm{~min}$ after HFS stimulation. Results in $C$ and $E$ represent means $\pm \operatorname{SEM}(n=6) ;{ }^{*} P<0.05 ;{ }^{* *} P<0.01$. 


\section{$\beta$-AR-dependent metaplasticity requires PKA and ERK but not mammalian target of rapamycin (mTOR)}

To further define the cellular mechanisms mediating $\beta$-ARdependent metaplasticity, we asked whether cAMP-dependent PKA plays a role in priming LTP. PKA has been implicated in LTP and long-term memory formation (Abel et al. 1997; Nayak et al. 1998; Oh et al. 2006) and can be recruited by $\beta$-AR activation (Thomas et al. 1996). Is PKA required for the enhancement of LTP by prior $\beta$-AR activation? To address this question, the PKA antagonist KT5720 was coapplied during ISO bath application. We found that activation of PKA was necessary for the metaplastic increase in synaptic response, as KT5720 blocked the subsequent induction of LTP (Fig. 6A; fEPSPs were 103\% $\pm 8 \%$ of baseline levels $120 \mathrm{~min}$ after HFS; $P<0.01$ compared with ISO plus HFS).

$\beta$-ARs can also recruit ERK, as well as another kinase, mTOR (Gelinas and Nguyen 2005; Gelinas et al. 2007), both of which 2007) and the long-term stability of LTP (Tang et al. 2002; Kelleher et al. 2004; Sweatt 2004). ERK regulates translation through Mnk1, which phosphorylates the eukaryotic translation initiation factor 4E (eIF4E) (Pyronnet et al. 1999; Waskiewicz have been implicated in local protein synthesis (Gelinas et al.

et al. 1999; Banko et al. 2004). ERK-mediated phosphorylation of eIF4E has been implicated in translation-dependent LTP (Gelinas et al. 2007) and memory formation (Kelleher et al. 2004). To determine if ERK is involved in ISO-triggered metaplasticity, we applied U0126, an inhibitor of mitogen-activated protein kinase kinase (MEK), which is the only known kinase upstream of ERK. Slices treated with U0126 exhibited significantly reduced levels of potentiation following stimulation (Fig. 6C; fEPSPs were $100 \% \pm 6 \%$ of baseline levels 120 min after HFS; $P<$ 0.01 compared with controls). These results suggest that ERK is required for metaplasticity induced by activation of $\beta$-ARs.

Another important component of the translational signaling pathway implicated in $\beta$-AR-dependent LTP is mTOR, which regulates protein synthesis by phosphorylating and inactivating a repressor of mRNA translation, eukaryotic initiation factor 4E-binding protein, 4E-BP (Beretta et al. 1996). Beretta et al. (1996) have shown that mTOR is blocked by rapamycin. Phosphorylation of rapamycin-sensitive sites on 4E-BP disrupts the binding of $4 \mathrm{E}-\mathrm{BP}$ and eIF4E, allowing for $4 \mathrm{E}$ to bind eIF4G. This $4 \mathrm{E}-4 \mathrm{G}$ binding is critical for formation of the translation initiation complex eIF4F (Klann et al. 2004).

Disruption of the mTOR signaling cascade attenuates LTP expression generated by HFS (Tang et al. 2002). However, application of rapamycin at $1 \mu \mathrm{M}$, a concentration that blocks $\beta$-AR-induced phosphorylation of 4E-BP (Gelinas et al.
A
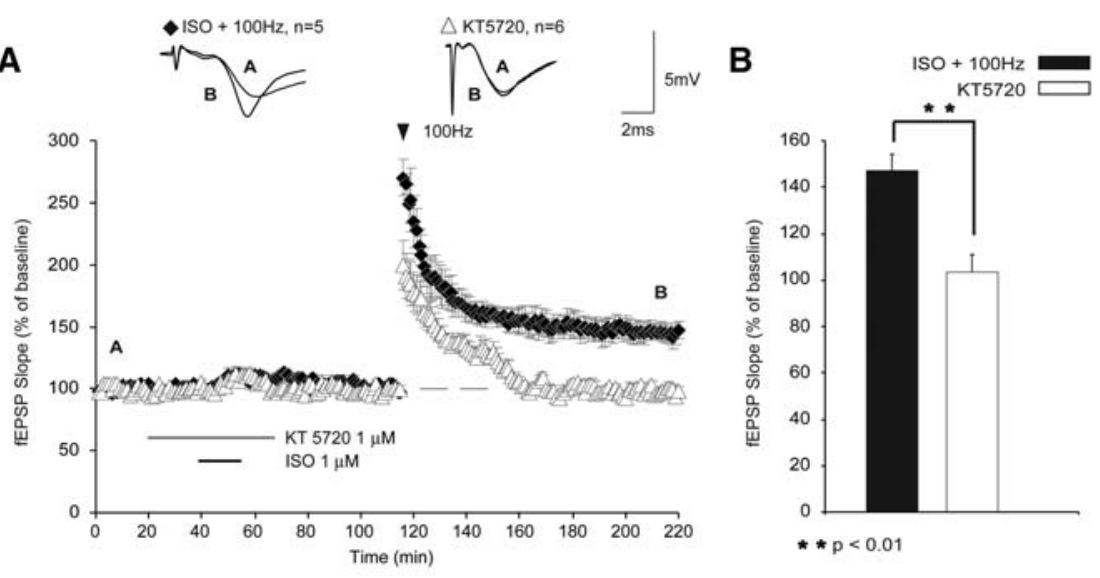

C

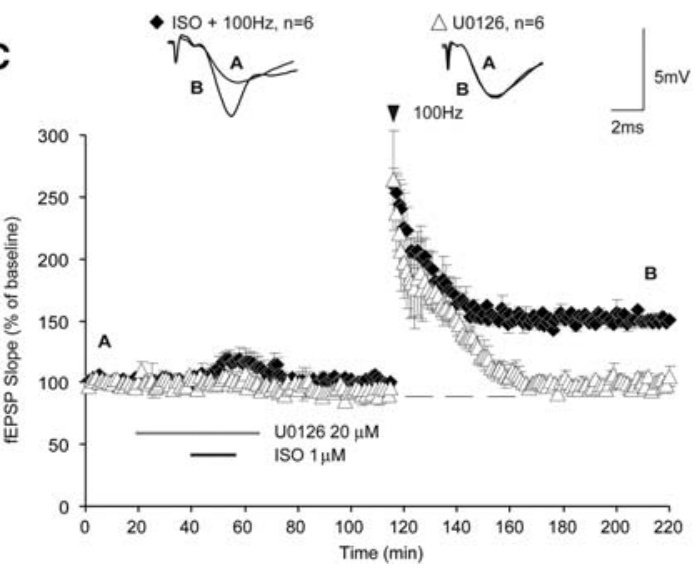

B

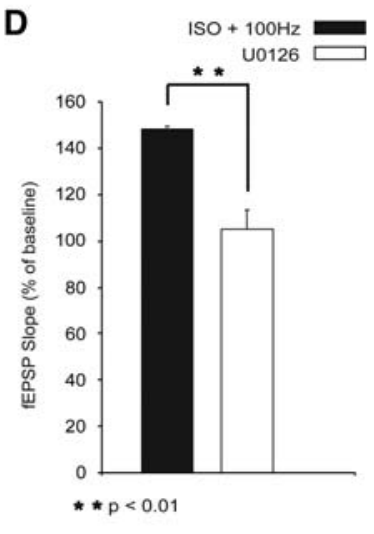

Figure 6. ERK and PKA are required for $\beta$-AR-dependent metaplasticity. (A) U0126, a MEK inhibitor applied during $\beta$-AR activation blocked metaplasticity (open triangles). (B) Summary histogram comparing fEPSP slopes 120 min after HFS $(n=6)$. (C) HFS applied following $\beta$-AR activation induced L-LTP (black diamonds), which was blocked in the presence of KT5720 (a PKA inhibitor) overlapping with ISO application (open triangles). (D) Summary histogram for these experiments $(n=6)$. Sample traces were taken 10 min after commencement of baseline recordings and 120 min after HFS stimulation. Results in $B$ and $D$ represent means $\pm \mathrm{SEM} ;{ }^{* *} P<0.01$. 2007), did not block $\beta$-AR-mediated priming of LTP (Fig. 7A; fEPSPs were potentiated to $143 \% \pm 6 \% 120 \mathrm{~min}$ after HFS). These results indicate a mechanistic divergence wherein ISO paired with HFS generates LTP that requires ERK and mTOR but not PKA (Gelinas and Nguyen 2005) and a metaplastic effect which requires ERK and PKA but not mTOR.

\section{GluA1 phosphorylation at S845 is persistently enhanced following $\beta$-AR stimulation}

To examine the effects of $\beta$-AR activation on phosphorylation of AMPA receptor GluA1 subunits, we used phospho-sitespecific antibodies and Western immunoblotting to test for potential changes in GluA1 phosphorylation at S845. In these experiments, CA1 minislices obtained from the same animal were either left untreated or exposed to a 10-min bath application of $1 \mu \mathrm{M}$ ISO and then collected for analysis either immediately after ISO application, 60 min after ISO washout, or $120 \mathrm{~min}$ after ISO washout. ISO had no effect on total GluA1 levels but induced an approximately fourfold increase in GluA1 phosphorylation at S845 immediately after ISO application $(435 \% \pm 44 \%$ of untreated control slices, $n=6, P<0.05$; Fig. 8). Consistent with the results of a previous study showing that $\beta$-AR activation induces an increase in GluA1 phosphorylation that persists for at least $1 \mathrm{~h}$ after ISO application (Vanhoose and Winder 2003), levels of S845 phosphorylated GluA1 were still significantly 


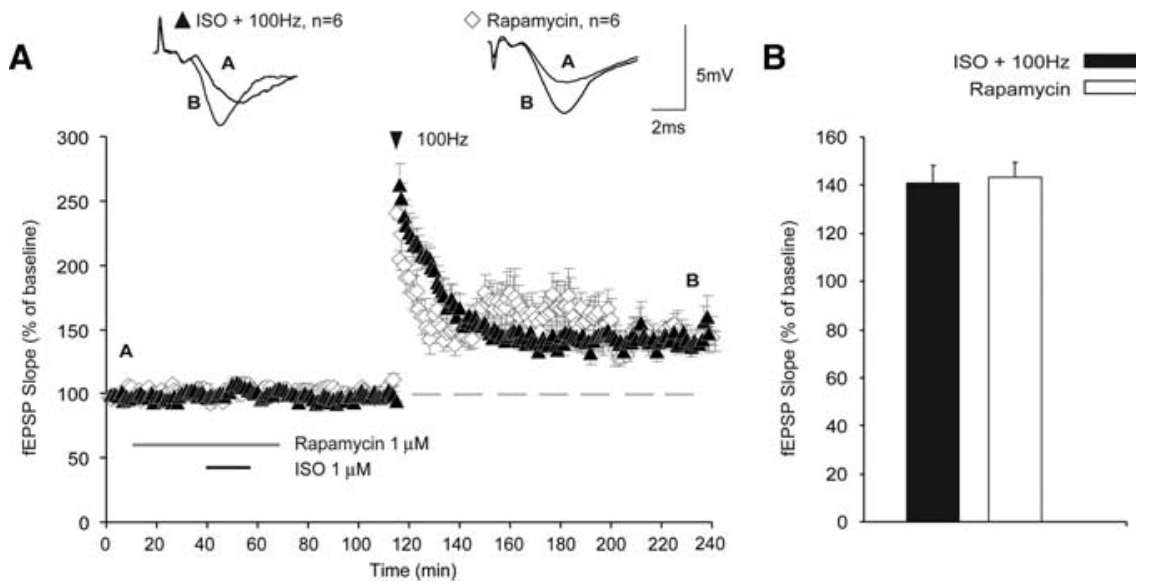

Figure 7. $m$ TOR is not required for metaplasticity engaged through $\beta$-ARs. (A) Application of rapamycin did not inhibit the subsequent induction of LTP generated by HFS $1 \mathrm{~h}$ after ISO application (filled squares). (B) Summary histogram comparing fEPSP slopes 120 min after HFS. All sample traces were taken $10 \mathrm{~min}$ after commencement of baseline recording and $120 \mathrm{~min}$ after stimulation protocol. Results in $B$ represent means $\pm \operatorname{SEM}(n=6)$.
(1.47 $\pm 0.06, \quad n=11, \quad P=0.008), \quad$ but this did not differ from ISO treatment alone $(P=0.677)$. These data confirm that ISO treatment increases the expression of GluA1-containing receptors at the cell surface. As we have previously shown that LTP-induced trafficking of some glutamate receptors is dependent on new protein synthesis (Williams et al. 2007), we tested whether the ISOinduced increase in surface GluA1 levels was translation-dependent. When ISO was applied in the presence of EME, there was a complete block of the ISO triggered increase in cell surface GluA1 levels $(0.82 \pm 0.09, n=10, P=0.009)$. These data suggest that protein synthesis either promotes the expression of molecules required to traffic GluA1 to the cell surface or is required to maintain constitutively expressed GluA1 at the cell surface. elevated $60 \mathrm{~min}$ after ISO washout $(358 \% \pm 47 \%$ of untreated control slices, $n=6, P<0.05$ ). Even $2 \mathrm{~h}$ after ISO application GluA1 phosphorylation at $\mathrm{S} 845$ was still elevated more than twofold compared with untreated control slices (levels were $246 \% \pm$ $20 \%$ of baseline, $n=6, P<0.05$ ). ERK activation is thought to importantly contribute to the modulatory effects of $\beta$-AR activation on LTP induction (Gelinas and Nguyen 2005) and, consistent with previous studies (Winder et al. 1999), we found that ISO induced a robust increase in levels of dually phosphorylated ERK1/2 (196\% $\pm 22 \%$ of untreated control slices immediately after ISO application, $n=6, P<0.05)$. However, in contrast to the prolonged increase in GluA1 phosphorylation at S845 induced by ISO, the increase in phospho-ERK1/2 levels was transient and decayed to control levels by $60 \mathrm{~min}$ after ISO washout (110\% $\pm 13 \%$ of baseline, $n=6$ ).

\section{$\beta$-AR activation drives protein synthesis-dependent membrane insertion of GluAl}

Having shown that ISO increases phosphorylation of GluA1 at S845, we hypothesized that this may be associated with increased insertion or retention of GluA1 at the cell surface (Sun et al. 2005; Gao et al. 2006; Oh et al. 2006). To investigate this, we treated hippocampal slices with ISO (1 $\mu \mathrm{M}, 15 \mathrm{~min})$ and isolated the cell surface proteins by applying the membrane impermeable biotin moiety, sulpho-NHS-SS-biotin, in conjunction with neutravidin pulldown assays (Williams et al. 2007). Using this methodology, we found that ISO significantly increased the levels of cell surface GluA1 relative to the no-drug control (1.4 $\pm 0.07, n=11, P=0.038$; Fig. 9). ISO given $1 \mathrm{~h}$ before HFS also resulted in a significant increase in GluA1 levels
A GluA1
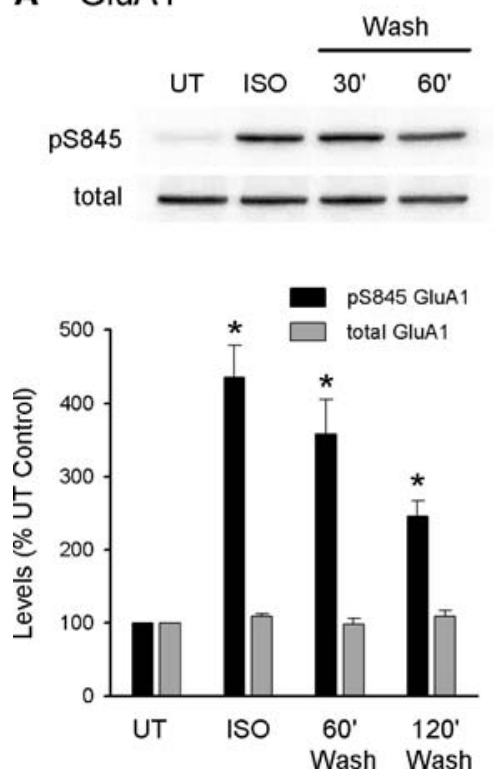

\section{Discussion}

Neuromodulators can modify the ability of synapses to undergo plasticity on timescales that extend well beyond normal synaptic transmission. Our results confirm previous studies showing that signals from neuromodulatory and neurotransmitter receptors can be integrated on extended timescales lasting at least $1 \mathrm{~h}$ (Christie and Abraham 1992; Huang et al. 1992; Cohen and Abraham 1996). In the present case, although application of a
Figure 8. $\beta-A R$ activation induces a persistent increase in GluA1 phosphorylation at S845. (A) Slices from the same animal were either untreated (UT) or exposed to $1 \mu \mathrm{M}$ ISO for $10 \mathrm{~min}$. ISO-treated slices where then collected for analysis either immediately after ISO application or after perfusion with agonist-free aCSF for 60 or 120 min. GluA1 phosphorylation at S845 was significantly elevated compared with untreated controls at all time points tested ( ${ }^{*} P<0.05$ compared with UT, $\left.n=6\right)$. In contrast, ISO had no effect on total GluA1 levels. $(B) \beta$-AR activation induced a transient activation of ERK1/2. Although phospho-ERK $1 / 2$ levels were significantly increased immediately after ISO application $\left({ }^{*} P<\right.$ 0.05 compared with UT), they returned to control levels following ISO washout. Western blots were run using the same samples used for the experiments shown in panel $A$. 


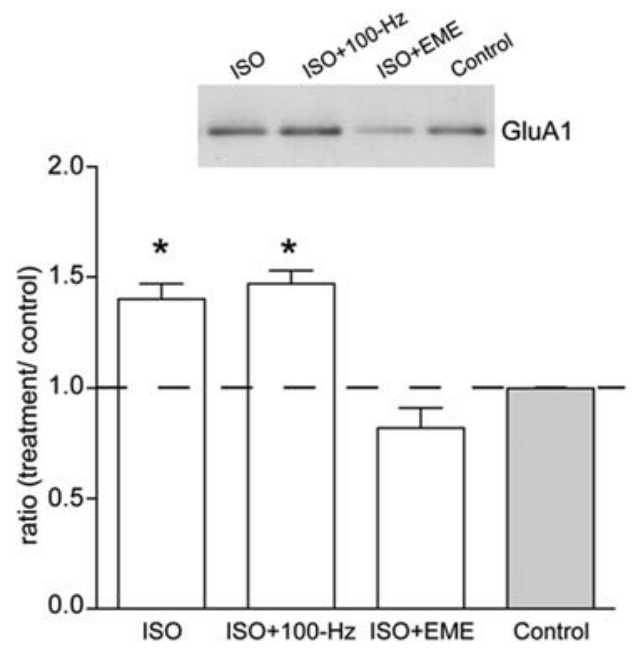

Figure 9. ISO treatment increases cell surface GluA1 levels. (Inset) Representative Western blot showing GluA1 levels $(\sim 106 \mathrm{kDa})$ in cellsurface extracts isolated from ISO, ISO $+100-\mathrm{Hz} \mathrm{HFS}$, ISO + EME, and control slices $(n=7-11)$. Summary graph showing that ISO induced a protein synthesis-dependent increase in GluA1 cell surface levels relative to the no-drug control, which was not additionally affected by $\mathrm{HFS}^{*}{ }^{*} P$ $<0.05$.

$\beta$-AR agonist to area CA1 of the hippocampus elicited only a very transient enhancement of synaptic strength, it substantially increased the magnitude and duration of LTP. Thus, a decremental LTP that does not require protein synthesis was converted to a translation-dependent, long-lasting LTP. The enhanced duration of LTP reflects the integration of diverse intracellular signals and provides a mechanism by which activation of neuromodulatory receptors can regulate synaptic plasticity subsequent to synaptic activity.

What are the mechanisms underlying $\beta$-AR-dependent metaplasticity? Metaplasticity induced by prior $\beta$-AR activation was immune to DPT, suggestive of a requirement for translation (Woo and Nguyen 2003). Inhibiting translation during $\beta$-AR activation but not during HFS, prevented LTP from being expressed. Importantly, shifting the application of ANI to overlap with HFS did not block the induction or expression of LTP, suggesting that previous activation of $\beta$-ARs is sufficient for priming translational processes that once engaged, are no longer sensitive to protein synthesis arrest. Previous results indicate that isoproterenol applied during HFS induces LTP that is sensitive to translation inhibition (Gelinas and Nguyen 2005). Here, we have delayed HFS to $1 \mathrm{~h}$ after $\beta$-AR stimulation. In both our present and previous studies (Gelinas and Nguyen 2005), LTP was blocked only when protein synthesis inhibition coincided with $\beta$-AR activation. Thus, $\beta$-ARs appear to up-regulate translation necessary for subsequent expression of LTP, whereas HFS plays a role in induction of synaptic potentiation. Indeed, the induction of LTP primed by $\beta$-ARs was blocked when the NMDAR antagonist APV was applied during HFS.

In a broader perspective, as translation is required for LTP expression (Bradshaw et al. 2003; Gelinas and Nguyen 2005; Abraham and Williams 2008) and formation of long-term memories (Moncada and Viola 2007; Hernandez and Abel 2008), our data provide insight into the cellular mechanisms that may be required for associative memory processes that allow for incorporation of temporally separated components of an experience.

What roles do PKA and ERK play in the metaplasticity processes engaged by $\beta$-AR activation? Stimulation of $\beta$-ARs initiates
ERK and mTOR signaling cascades, which independently converge at regulation of the translation factor eIF4E during $\beta$-ARdependent LTP (Gelinas et al. 2007). ERK has been implicated in translational control of synaptic plasticity (Kelleher et al. 2004; Gelinas and Nguyen 2005; Gobert et al. 2008) and memory processes (Kelly et al. 2003; Duvarci et al. 2005; for review, see Sweatt 2004; Giovannini 2006). ERK regulates protein synthesis through a Mnk1-mediated phosphorylation of eIF4E, which has been associated with increased rates of translation (Panja et al. 2009). Interestingly, mTOR inhibition did not block the $\beta$-ARinduced metaplasticity observed in the current study. Previous results from our lab determined that mTOR is required for LTP induced by pairing ISO application with HFS (Gelinas and Nguyen 2005). This suggests a divergence in mechanisms supporting these types of plasticity. For metaplasticity, ERK signaling may generate a long-lasting (at least $1 \mathrm{~h}$ ) state of primed translation that does not require mTOR. Functionally, this may relate to the saliency of the signals; the contiguous protocol may represent a "strong" signal that initiates immediate, long-term changes in synaptic strength through multiple signaling cascades coregulating translation. Metaplastic processes, on the other hand, must by nature be highly labile to allow for incorporation of signals over time, and therefore may not require the same magnitude of translation regulation observed with "strong" stimuli.

Emetine and anisomycin inhibit translation by blocking the $48 \mathrm{~S}$ ribosome, whereas rapamycin blocks translation by inhibiting phosphorylation of $4 \mathrm{E}-\mathrm{BP}$, precluding assembly of the preinitiation complex at the $5^{\prime}$ caps of target mRNAs. Interestingly, our $\beta$-AR-dependent metaplasticity did not require activation of mTOR, as it was not blocked by rapamycin. This suggests that capindependent translation, involving internal ribosomal entry sites (IRES) (reviewed by Klann et al. 2004), may be recruited by activation of $\beta$-ARs $1 \mathrm{~h}$ prior to LTP induction. Some dendritic mRNAs that are known to contain IRESs and that may be translated in a cap-independent manner include Arc (activity-regulated cytoskeletal protein), CaMK2- $\alpha$, and MAP2 (microtubule associated protein-2) (Pinkstaff et al. 2001). Further research is needed to directly assess the involvement of cap-independent translation, and of these specific proteins, in $\beta$-AR-induced metaplasticity of LTP.

Activation of $\beta$-ARs can increase phosphorylation of AMPARs in a PKA-dependent manner (Man et al. 2007). The increased surface expression of GluA1 observed in the present study suggests one mechanisms of $\beta$-AR metaplasticity, namely, trafficking of GluA1-containing AMPARs to the cell surface through a PKA-dependent phosphorylation of $\$ 845$ and protein synthesis. Recent work suggests that PKA phosphorylation of GluA1 S845 regulates AMPAR surface expression by both increasing receptor insertion and decreasing internalization (Man et al. 2007). Phosphorylation of S845 can also enhance the subsequent activity-dependent insertion of GluA1 by mobilizing AMPARs to extrasynaptic locations (Oh et al. 2006). The role of translation in this process is less clear, but a similar effect has been reported following LTP in the dentate gyrus in vivo, although for subunits other than GluR1 (Williams et al. 2007). While the identities of the synthesized proteins remain to be determined, they could include molecular chaperones important for the trafficking process, as the total level of GluA1 itself is not changed. Regardless, the localization of GluRs extrasynaptically is an attractive metaplasticity mechanism, as this positions them for activity-dependent lateral movement into the synapse, thereby enhancing the subsequent LTP. This mechanism could help explain the previously reported increase in the induction of LTP following ISO priming (Cohen et al. 1999).

Monitoring baseline responses to application of ISO alone revealed a transient increase in potentiation which returned to 
baseline in $<20 \mathrm{~min}$. This suggests that activation of $\beta$-ARs alone is insufficient for the induction of LTP. However, stimulation of $\beta$-ARs appears to engage a long-lasting $(1 \mathrm{~h})$ priming mechanism that facilitates the activity-dependent mobilization of AMPARs to synaptic locations required for LTP. Synaptic incorporation of AMPARs appears to be an NMDA-receptor-dependent event as application of the NMDAR antagonist overlapping with HFS blocked the induction of LTP. Thus, the role of HFS in this protocol may be to drive the synaptic incorporation of AMPARs through $\mathrm{Ca}^{2+}$-dependent events, which may stabilize AMPARs synaptically by regulating receptor anchoring (Borgdorff and Choquet 2002; Tardin et al. 2003).

Our results provide novel evidence for a $\beta$-AR-dependent facilitation of subsequent induction of LTP on timescales requiring metaplastic mechanisms. Because persistent LTP requires de novo protein synthesis, $\beta$-ARs may engage translation to gate the future establishment of long-lasting plasticity. As $\beta$-ARs also couple to PKA and ERK-dependent signaling cascades, this provides a biochemical mechanism for the metaplastic enhancement of LTP generated by prior activation of $\beta$-ARs (Fig. 10). Here, we established that $\beta$-AR-dependent metaplasticity recruits PKA and ERK activation as LTP was attenuated by inhibition of either PKA or ERK during ISO application. Inhibition of translation with EME or ANI blocked the expression of LTP but only when inhibitors were applied overlapping with ISO and well before LTP induction. The effects of translational inhibition appear to affect stabilization of GluA1 membrane insertion, which was increased following stimulation of $\beta$-AR, but reduced in the presence of EME. Indeed, activation of $\beta$-ARs increased GluA1 phosphorylation at site S845, which facilitates membrane insertion of GluA1 (Man et al. 2007). Our data suggest a metaplastic mechanism whereby stimulation of $\beta$-ARs primes synaptic incorporation of GluA1 through phosphorylation and translation-dependent stabilization of recently inserted receptors.

In summary, our data characterize the biochemical signaling mechanisms by which activation of $\beta$-ARs can enhance the future persistence of LTP. Metaplasticity mechanisms engaged by neuromodulators, by enhancing translation regulation, could facilitate the encoding of information presented on timescales much longer than normal synaptic transmission. Our data add the $\beta$-AR to a growing number of neuromodulatory receptors that when activated alter the threshold for future changes in synaptic strength. Under circumstances that require attention or elicit arousal, global levels of NA increase (Berridge and Waterhouse 2003). Release of NA lowers the threshold for subsequent synaptic change by priming translational processes necessary for long-term synaptic modifications (Gelinas and Nguyen 2007). Our results suggest that the priming effect of $\beta$-AR activation was limited to $1 \mathrm{~h}$, despite the persistence of GluA1 phosphorylation for at least $2 \mathrm{~h}$. As shifting the application of anisomycin beyond ISO application failed to block the subsequent induction of LTP, this suggests a time-limited role for translational regulation in priming of future synaptic events. In the course of everyday events, experience is best framed in the second to minute to hour time frame (Dudai 2009). Therefore, an effective way for updating of a previously established memory would be to encode information that presents within a limited $(<1 \mathrm{~h})$ time window relative to the plasticity-inducing stimulus. This also raises the possibility that NA acting at $\beta$-ARs obviates the need for ongoing attentional processes to facilitate association of new items into the previously established memory as primed plasticity mechanisms would lower the threshold for subsequent changes in synaptic efficacy supporting memory updating. This would be an efficient method for ensuring that information that may have value is properly encoded in association with the initial priming event.

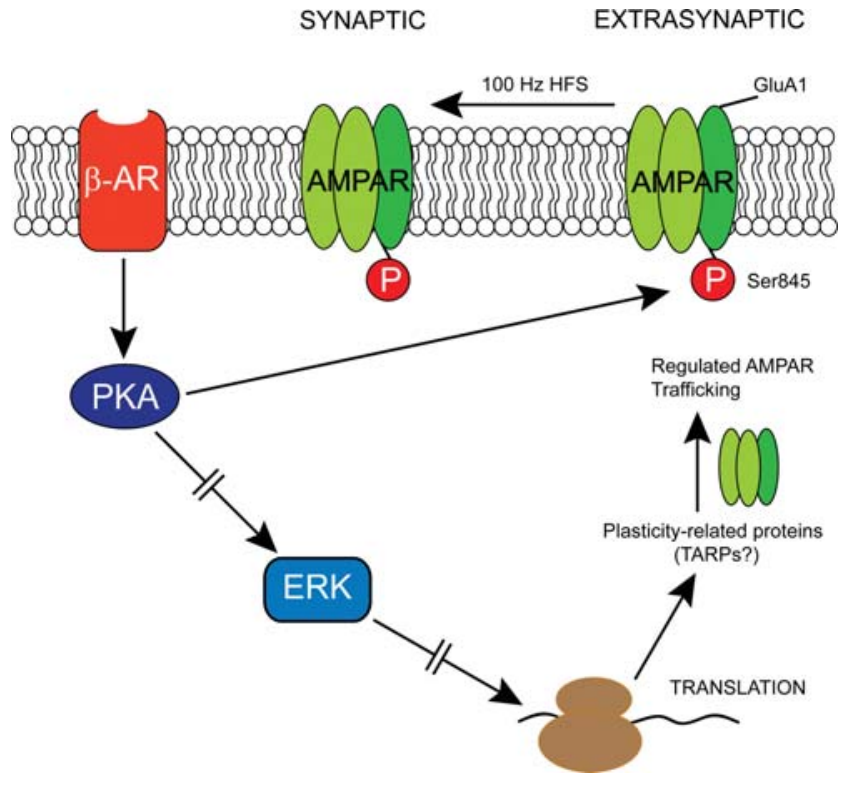

Figure 10. Hypothetical model for primed AMPAR mobility following $\beta$-AR activation. $\beta$-ARs facilitate AMPAR insertion through PKA-dependent phosphorylation of GluR intracellular C-terminal domains and translation of plasticity related proteins (PRPs), which may include transmembrane AMPAR regulatory proteins (TARPs) that regulate AMPAR trafficking. PKA phosphorylation of S845 on GluA1 and newly synthesized PRPs increase AMPAR expression at extrasynaptic sites. HFS may drive lateral mobilization of AMPARs into the synapse resulting in enhanced synaptic strength.

\section{Materials and Methods}

\section{Hippocampal slice preparation}

Male C57BL/6 mice (8-13 wk) (Charles River, Montréal, Québec, Canada) were used for all experiments. Animals were housed and cared for at the University of Alberta using guidelines approved by the Canadian Council on Animal Care. After cervical dislocation and decapitation, transverse hippocampal slices (400 $\mu \mathrm{m}$ thick) were prepared as described by Nguyen and Kandel (1997). Slices were maintained in an interface chamber at $28^{\circ} \mathrm{C}$ and perfused 1-2 $\mathrm{ml} / \mathrm{min}$ with artificial CSF (aCSF) composed of the following (in mM): $124 \mathrm{NaCl}, 4.4 \mathrm{KCl}, 1.3 \mathrm{MgSO}_{4}, 1.0 \mathrm{NaH}_{2} \mathrm{PO}_{4}, 26.2$ $\mathrm{NaHCO}_{3}, 2.5 \mathrm{CaCl}_{2}$, and 10 glucose, aerated with $95 \% \mathrm{O}_{2}$ and $5 \% \mathrm{CO}_{2}$. Slices recovered for $60 \mathrm{~min}$ before experiments commenced.

\section{Electrophysiology}

fEPSPs were recorded with a glass microelectrode filled with aCSF (resistances, 2-3 M $\Omega$ ) and positioned in the stratum radiatum of area CA1. fEPSPs were elicited by using bipolar nickel-chromium electrodes placed in stratum radiatum to stimulate inputs converging onto CA1 apical dendrites. The stimulation intensity (0.08-msec pulse duration; Grass S48 stimulator) was adjusted to evoke fEPSP amplitudes that were $40 \%$ of maximal size (Woo and Nguyen 2003; Gelinas and Nguyen 2007). Subsequent fEPSPs were elicited at the rate of $1 / \mathrm{min}$ at this "test" stimulation intensity. fEPSPs were amplified and digitized using a Digidata 1200B Interface (Molecular Devices). Axon Clampfit 9.0 (Molecular Devices) was used for offline analysis. LTP was induced by applying a brief HFS (1-sec duration, $100 \mathrm{~Hz}) 1$ or $2 \mathrm{~h}$ after ISO application. DPT was induced by applying LFS ( $5 \mathrm{~Hz}, 3 \mathrm{~min}) 10$ min after induction of LTP (Woo and Nguyen 2003).

\section{Drugs}

ISO, a specific $\beta$-AR agonist, $(R[-]$ - isoproterenol [+]-bitartrate, 1 $\mu \mathrm{M}$; Sigma) was prepared fresh daily in distilled water as a $2 \mathrm{mM}$ 
stock solution. The $\beta$-AR antagonist ( \pm )-propranolol hydrochloride (PROP; $50 \mu \mathrm{M}$; Research Biochemicals) was also prepared daily in distilled water as a 50-mM stock solution. The NMDAR antagonist, APV (DL-2-amino-5-phosphonopentanoic acid, $50 \mu \mathrm{M}$; Sigma) was prepared in distilled water as a $50-\mathrm{mM}$ stock solution. An mTOR inhibitor, rapamycin (1 $\mu \mathrm{M}$; Sigma) and a MEK inhibitor, U0126 (20 $\mu \mathrm{M}$; Sigma), were prepared in dimethyl sulfoxide (DMSO) in stock concentrations at $1 \mathrm{mM}$ and $20 \mathrm{mM}$, respectively. Methanol was used to dissolve the PKA inhibitor KT5720 ( $1 \mu \mathrm{M}$ final concentration in aCSF; Sigma) as a 1 -mM stock solution. Two protein synthesis inhibitors, ANI ( $40 \mu \mathrm{M}$; Sigma) and EME ( $20 \mu \mathrm{M}$; Sigma), were prepared as $40-\mathrm{mM}$ stock solutions in DMSO and $20 \mathrm{mM}$ in distilled water, respectively. Both ANI and EME, at lower concentrations than those used here, blocked protein synthesis by $>80 \%$ in hippocampal slices (Frey et al. 1988). The diluted bath concentrations of DMSO (0.1\%) and methanol $(0.1 \%)$ did not affect either basal synaptic transmission or LTP (data not shown). KT5720 and U0126 were applied for $20 \mathrm{~min}$ before ISO and remained in the bath for an additional $25 \mathrm{~min}$ thereafter. APV, propranolol, ANI, EME, and rapamycin were applied $30 \mathrm{~min}$ before ISO application, throughout ISO application, and for $10 \mathrm{~min}$ after ISO application. All drug experiments were performed under dimmed light conditions due to drug photosensitivity. Drug experiments were interleaved with drug-free controls.

\section{Data analysis}

The initial slope of the fEPSP was measured as an index of synaptic strength (Johnston and $\mathrm{Wu}$ 1995). The average "baseline" slope values were acquired over a period of $20 \mathrm{~min}$ before experimental protocols and all fEPSP initial slope measurements were expressed as a percentage of the baseline. fEPSP slopes were measured at 120 min post-stimulation for comparisons of LTP. Student's $t$-test was used for statistical comparisons of mean fEPSP slopes between two groups, with a significance level of $P<0.05$. All values shown are means \pm SEM, with $n=$ number of slices.

\section{Preparation of cell surface fractions}

Hippocampal cell-surface proteins were isolated by reversible tagging with a membrane-impermeable biotin moiety and precipitated by addition of Neutravidin conjugated to agarose beads using a method based on our established protocol (Williams et al. 2007), with modifications. Slices $(400 \mu \mathrm{m})$ were bathed in $\operatorname{aCSF}\left(2 \mathrm{~h} / 28^{\circ} \mathrm{C}\right)$ with constant perfusion, prior to treatment (15 min). Groups included no drug $(n=7), 1 \mu \mathrm{M}$ ISO $(n=11), 1 \mu \mathrm{M}$ ISO + HFS $(n=11)$, and $1 \mu \mathrm{M}$ ISO $+20 \mu \mathrm{M}$ EME $(n=10)$. After washout $(1 \mathrm{~h})$, slices were removed to ice-cold aCSF $(5 \mathrm{~min})$ followed by incubation with $2.5 \mathrm{mg} / \mathrm{mL}$ sulpho-NHS-SS-biotin (Pierce 21331). Unreacted biotin was quenched by addition of $20 \mathrm{mM}$ Tris $\mathrm{pH} 7.4$ and removed by extensive washing. Area CA1 was microdissected and frozen on dry ice prior to sonication in Solubilization buffer (1 mM EGTA, 1 mM EDTA, 1 mM PMSF, Complete protease inhibitor [Roche Diagnostics Ltd.], 1\% Triton $\mathrm{X}-100$ in phosphate buffer saline). Cell surface proteins were precipitated by addition of Neutravidin conjugated to agarose beads (Pierce, 29200; $2 \mathrm{~h}, 4^{\circ} \mathrm{C}$ ) and released from the pull-down complex by incubation in $50 \mathrm{mM}$ Tris.Cl, 1\% SDS, $100 \mathrm{mM}$ DTT (10 min, $99^{\circ} \mathrm{C}$ ) prior to Western blot analysis (Williams et al. 1998, 2007). Membranes were probed with an antibody recognizing GluA1 (Abcam ab31232; Cambridge), and detected using HRP-conjugated secondary antibodies and Supersignal West Pico (Pierce). The experimenter analyzed the results while blind to experimental condition. To determine whether there was a significant difference between treatment groups the data were subjected to two-tailed Student $t$-tests, where a probability level of $\leq 0.05$ was accepted as statistically significant.

\section{Phosphorylation status immunoblotting}

To examine the effects of $\beta$-AR activation on phosphorylation of AMPA receptor GluA1 subunits and ERK activation, we use CA1 "minislices" that were prepared by removing the dentate gyrus, CA3 region, and subiculum from freshly cut, $400 \mu \mathrm{m}$-thick hippocampal slices. CA1 minislices were then maintained in interface-type slice chambers (typically three to six slices/chamber) perfused $(2 \mathrm{~mL} / \mathrm{min})$ with warm $\left(28^{\circ} \mathrm{C}\right)$, oxygenated aCSF, and allowed to recover for at least $2 \mathrm{~h}$. Slices were then either left in aCSF (untreated controls) or exposed to a $10 \mathrm{~min}$ bath application of ISO $(1 \mu \mathrm{M})$ and collected for analysis either immediately after ISO application or at different time points following washout of ISO with drug-free aCSF. In all groups slices were snap-frozen by rapidly transferring them into prechilled microcentrifuge tubes (Kontes Glass Company) and plunging the tube into a bed of crushed dry ice.

For Western blot analysis the slices were homogenized in ice-cold buffer containing $50 \mathrm{mM}$ Tris- $\mathrm{HCl}, 50 \mathrm{mM} \mathrm{NaF}, 10 \mathrm{mM}$ EGTA, $10 \mathrm{mM}$ EDTA, $80 \mu \mathrm{M}$ sodium molybdate, $5 \mathrm{mM}$ sodium pyrophosphate, $1 \mathrm{mM}$ sodium orthovanadate, $1 \mathrm{mM}$ phenylmethylsulfonyl fluoride, $0.01 \%$ Triton $\mathrm{X}-100$, and $4 \mathrm{mM}$ paranitrophenylphosphate that contained both protease inhibitors (Protease Inhibitors Complete, Roche Molecular Biochemicals) and protein phosphatase inhibitors (Phosphatase Inhibitor Cocktails I and II; Sigma-Aldrich). Aliquots from each of the samples were removed to determine protein concentration using the Bradford assay and samples were then boiled for 5 min after the addition of $2 \times$ loading buffer. Equal amounts of total protein (20 $\mathrm{\mu g}$ /lane) from each of the samples were resolved on $12 \%$ SDS-PAGE gels, transferred onto nitrocellulose membranes, and then blocked for $1 \mathrm{~h}$ in Tris-buffered saline containing $0.05 \%$ Tween-20 (TBST) and 4\% fat-free dry milk. Primary antibody incubations were done overnight $\left(\right.$ at $\left.4^{\circ} \mathrm{C}\right)$ and, following three washes in TBST, blots were incubated for $2-4 \mathrm{~h}$ at room temperature in the appropriate HRP-conjugated secondary antibody. Immunoreactive bands were visualized using enhanced chemiluminescence and a cooled CCD camera-based image acquisition and analysis system (Quantity One; Bio-Rad) was used to acquire images of the blots and perform densitometric analysis. All blots were reprobed with an antitubulin antibody and the optical density values for each band of interest was normalized to the density values obtained for tubulin in the same lane to control for potential variations in loading. These values were then normalized to levels for the same protein measured in samples from untreated control slices. Friedman repeated-measures ANOVA on ranks followed by Student-Newman-Keuls tests for multiple pair-wise comparisons were used to determine statistical significance.

Antibodies to GluA1 (1:2000) and phospho-S845 GluA1 (1:1000) were obtained from Upstate Biotechnology. Antibodies to GluA1 (1:1000) and phospho-T840 GluA1 (1:2000) were obtained from Abcam. Antibodies to dually phosphorylated ERK1/2 (1:1000) and total ERK1/2 (1:1000) were obtained from Cell Signaling Technology.

\section{Acknowledgments}

This research was supported by grants from the Canadian Institutes of Health Research (to P.V.N.), the National Institutes of Mental Health (MH609197 to T.J.O.), and the Royal Society of New Zealand, Marsden Fund (to J.W. and W.C.A.). S.A.C. received a Graduate Scholarship from the Natural Sciences and Engineering Research Council of Canada, and P.V.N. is a Scientist of the Alberta Heritage Foundation for Medical Research.

\section{References}

Abel T, Nguyen PV, Barad M, Deuel TA, Kandel ER, Bourtchouladze R. 1997. Genetic demonstration of a role for PKA in the late phase of LTP and in hippocampus-based long-term memory. Cell 88: 615-626.

Abraham WC. 2008. Metaplasticity-tuning synapses and networks for plasticity. Nat Rev Neurosci 9: 387-399.

Abraham WC, Bear MF. 1996. Metaplasticity: The plasticity of synaptic plasticity. Trends Neurosci 19: 126-130.

Abraham WC, Williams JM. 2008. LTP maintenance and its protein synthesis-dependence. Neurobiol Learn Mem 89: 260-268.

Alberini CM. 2008. The role of protein synthesis during the labile phases of memory: Revisiting the skepticism. Neurobiol Learn Mem 89: 234-246. 
Banko JL, Hou L, Klann E. 2004. NMDA receptor activation results in PKAand ERK-dependent Mnkl activation and increased eIF4E phosphorylation in hippocampal area CA1. J Neurochem 91: 462-470.

Beretta L, Gingras AC, Svitkin YV, Hall MN, Sonenberg N. 1996. Rapamycin blocks the phosphorylation of 4E-BP1 and inhibits cap-dependent initiation of translation. $E M B O J$ 15: $658-664$.

Berridge CW, Waterhouse BD. 2003. The locus coeruleus-noradrenergic system: Modulation of behavioral state and state-dependent cognitive processes. Brain Res Rev 42: 33-84.

Bliss TV, Collingridge GL. 1993. A synaptic model of memory: Long-term potentiation in the hippocampus. Nature 361: 31-39.

Bliss TV, Lomo T. 1973. Long-lasting potentiation of synaptic transmission in the dentate area of the anaesthetized rabbit following stimulation of the perforant path. J Physiol 232: 331-356.

Borgdorff AJ, Choquet D. 2002. Regulation of AMPA receptor lateral movements. Nature 417: 649-653.

Bradshaw KD, Emptage NJ, Bliss TV. 2003. A role for dendritic protein synthesis in hippocampal late LTP. Eur J Neurosci 18: 3150-3152.

Christie BR, Abraham WC. 1992. Priming of associative long-term depression in the dentate gyrus by theta frequency synaptic activity. Neuron 9: 79-84.

Cohen AS, Abraham WC. 1996. Facilitation of long-term potentiation by prior activation of metabotropic glutamate receptors. J Neurophysiol 76: 953-962.

Cohen AS, Coussens CM, Raymond CR, Abraham WC. 1999. Long-lasting increase in cellular excitability associated with the priming of LTP induction in rat hippocampus. J Neurophysiol 82: 3139-3148.

Collingridge GL, Kehl SJ, McLennan H. 1983. Excitatory amino acids in synaptic transmission in the Schaffer collateral-commissural pathway of the rat hippocampus. J Physiol 334: 33-46.

Dudai Y. 2009. Predicting not to predict too much: How the cellular machinery of memory anticipates the uncertain future. Philos Trans $R$ Soc Lond B Biol Sci 364: 1255-1262.

Duvarci S, Nader K, LeDoux JE. 2005. Activation of extracellular signal-regulated kinase-mitogen-activated protein kinase cascade in the amygdala is required for memory reconsolidation of auditory fear conditioning. Eur J Neurosci 21: 283-289.

Frey U, Krug M, Reymann KG, Matthies H. 1988. Anisomycin, an inhibitor of protein synthesis, blocks late phases of LTP phenomena in the hippocampal CA1 region in vitro. Brain Res 452: 57-65.

Fujii S, Saito K, Miyakawa H, Ito K, Kato H. 1991. Reversal of long-term potentiation (depotentiation) induced by tetanus stimulation of the input to CA1 neurons of guinea pig hippocampal slices. Brain Res 555: $112-122$.

Gao C, Sun X, Wolf ME. 2006. Activation of D1 dopamine receptors increases surface expression of AMPA receptors and facilitates their synaptic incorporation in cultured hippocampal neurons. J Neurochem 98: $1664-1677$.

Gelinas JN, Nguyen PV. 2005. Beta-adrenergic receptor activation facilitates induction of a protein synthesis-dependent late phase of long-term potentiation. J Neurosci 25: 3294-3303.

Gelinas JN, Nguyen PV. 2007. Neuromodulation of hippocampal synaptic plasticity, learning, and memory by noradrenaline. Cent Nerv Syst Agents Med Chem 7: 17-33.

Gelinas JN, Banko JL, Hou L, Sonenberg N, Weeber EJ, Klann E, Nguyen PV. 2007. ERK and mTOR signaling couple beta-adrenergic receptors to translation initiation machinery to gate induction of protein synthesis-dependent long-term potentiation. J Biol Chem 282: $27527-27535$

Giovannini MG. 2006. The role of the extracellular signal-regulated kinase pathway in memory encoding. Rev Neurosci 17: 619-634.

Gobert D, Topolnik L, Azzi M, Huang L, Badeaux F, Desgroseillers L, Sossin WS, Lacaille JC. 2008. Forskolin induction of late-LTP and up-regulation of $5^{\prime}$ TOP mRNAs translation via mTOR, ERK, and PI3K in hippocampal pyramidal cells. J Neurochem 106: 1160-1174.

Hernandez PJ, Abel T. 2008. The role of protein synthesis in memory consolidation: Progress amid decades of debate. Neurobiol Learn Mem 89: $293-311$.

Hu H, Real E, Takamiya K, Kang MG, Ledoux J, Huganir RL, Malinow R. 2007. Emotion enhances learning via norepinephrine regulation of AMPA-receptor trafficking. Cell 131: 160-173.

Huang CC, Liang YC, Hsu KS. 1999. A role for extracellular adenosine in time-dependent reversal of long-term potentiation by lowfrequency stimulation at hippocampal CA1 synapses. J Neurosci 19: 9728-9738.

Huang YY, Colino A, Selig DK, Malenka RC. 1992. The influence of prior synaptic activity on the induction of long-term potentiation. Science 255: $730-733$.

Johnston D, Wu SM-S. 1995. Foundations of cellular neurophysiology. MIT Press, Cambridge, MA.

Kandel ER. 2001. The molecular biology of memory storage: A dialogue between genes and synapses. Science 294: 1030-1038.
Katsuki H, Izumi Y, Zorumski CF. 1997. Noradrenergic regulation of synaptic plasticity in the hippocampal CA1 region. J Neurophysiol 77: 3013-3020.

Kelleher RJ 3rd, Govindarajan A, Jung HY, Kang H, Tonegawa S. 2004. Translational control by MAPK signaling in long-term synaptic plasticity and memory. Cell 116: 467-479.

Kelly A, Laroche S, Davis S. 2003. Activation of mitogen-activated protein kinase/extracellular signal-regulated kinase in hippocampal circuitry is required for consolidation and reconsolidation of recognition memory. J Neurosci 23: 5354-5360.

Klann E, Antion MD, Banko JL, Hou L. 2004. Synaptic plasticity and translation initiation. Learn Mem 11: 365-372.

Man HY, Sekine-Aizawa Y, Huganir RL. 2007. Regulation of $\alpha$-amino-3-hydroxy-5-methyl-4-isoxazolepropionic acid receptor trafficking through PKA phosphorylation of the Glu receptor 1 subunit. Proc Natl Acad Sci 104: 3579-3584.

Mellentin C, Jahnsen H, Abraham WC. 2007. Priming of long-term potentiation mediated by ryanodine receptor activation in rat hippocampal slices. Neuropharmacology 52: 118-125.

Moncada D, Viola H. 2007. Induction of long-term memory by exposure to novelty requires protein synthesis: Evidence for a behavioral tagging. $J$ Neurosci 27: 7476-7481.

Morris RG, Davis S, Butcher SP. 1990. Hippocampal synaptic plasticity and NMDA receptors: A role in information storage? Philos Trans $R$ Soc Lond B Biol Sci 329: 187-204.

Nayak A, Zastrow DJ, Lickteig R, Zahniser NR, Browning MD. 1998. Maintenance of late-phase LTP is accompanied by PKA-dependent increase in AMPA receptor synthesis. Nature 394: 680-683.

Nguyen PV, Kandel ER. 1996. A macromolecular synthesis-dependent late phase of long-term potentiation requiring cAMP in the medial perforant pathway of rat hippocampal slices. J Neurosci 16: 3189-3198.

Nguyen PV, Kandel ER. 1997. Brief theta-burst stimulation induces a transcription-dependent late phase of LTP requiring cAMP in area CA1 of the mouse hippocampus. Learn Mem 4: 230-243.

O'Connor JJ, Rowan MJ, Anwyl R. 1994. Long-lasting enhancement of NMDA receptor-mediated synaptic transmission by metabotropic glutamate receptor activation. Nature 367: 557-559.

O'Dell TJ, Kandel ER. 1994. Low-frequency stimulation erases LTP through an NMDA receptor-mediated activation of protein phosphatases. Learn Mem 1: $129-139$

O'Dell TJ, Connor SA, Gelinas JN, Nguyen PV. 2010. Viagra for your synapses: Enhancement of hippocampal long-term potentiation by activation of beta-adrenergic receptors. Cell Signal 22: $728-736$.

Oh MC, Derkach VA, Guire ES, Soderling TR. 2006. Extrasynaptic membrane trafficking regulated by GluR1 serine 845 phosphorylation primes AMPA receptors for long-term potentiation. J Biol Chem 281: $752-758$.

Panja D, Dagyte G, Bidinosti M, Wibrand K, Kristiansen AM, Sonenberg N, Bramham CR. 2009. Novel translational control in Arc-dependent long term potentiation consolidation in vivo. J Biol Chem 284: 31498-31511.

Pinkstaff JK, Chappell SA, Mauro VP, Edelman GM, Krushel LA. 2001. Internal initiation of translation of five dendritically localized neuronal mRNAs. Proc Natl Acad Sci 98: 2770-2775.

Pyronnet S, Imataka H, Gingras AC, Fukunaga R, Hunter T, Sonenberg N. 1999. Human eukaryotic translation initiation factor $4 \mathrm{G}$ (eIF4G) recruits Mnk1 to phosphorylate eIF4E. EMBO J 18: $270-279$.

Raymond CR, Thompson VL, Tate WP, Abraham WC. 2000. Metabotropic glutamate receptors trigger homosynaptic protein synthesis to prolong long-term potentiation. J Neurosci 20: 969-976.

Routtenberg A, Rekart JL. 2005. Post-translational protein modification as the substrate for long-lasting memory. Trends Neurosci $\mathbf{2 8 :}$ $12-19$.

Sajikumar S, Li Q, Abraham WC, Xiao ZC. 2009. Priming of short-term potentiation and synaptic tagging/capture mechanisms by ryanodine receptor activation in rat hippocampal CA1. Learn Mem 16: $178-186$.

Staubli U, Lynch G. 1990. Stable depression of potentiated synaptic responses in the hippocampus with 1-5 Hz stimulation. Brain Res 513: $113-118$.

Straube T, Korz V, Balschun D, Frey JU. 2003. Requirement of beta-adrenergic receptor activation and protein synthesis for LTP-reinforcement by novelty in rat dentate gyrus. J Physiol 552: 953-960.

Sun X, Zhao Y, Wolf ME. 2005. Dopamine receptor stimulation modulates AMPA receptor synaptic insertion in prefrontal cortex neurons. $J$ Neurosci 25: 7342-7351.

Sweatt JD. 2004. Mitogen-activated protein kinases in synaptic plasticity and memory. Curr Opin Neurobiol 14: 311-317. 
Tang SJ, Reis G, Kang H, Gingras AC, Sonenberg N, Schuman EM. 2002. A rapamycin-sensitive signaling pathway contributes to long-term synaptic plasticity in the hippocampus. Proc Natl Acad Sci 99: 467-472.

Tardin C, Cognet L, Bats C, Lounis B, Choquet D. 2003. Direct imaging of lateral movements of AMPA receptors inside synapses. EMBO J 22: $4656-4665$

Thomas MJ, Moody TD, Makhinson M, O’Dell TJ. 1996. Activitydependent beta-adrenergic modulation of low frequency stimulation induced LTP in the hippocampal CA1 region. Neuron 17: 475-482.

Vanhoose AM, Winder DG. 2003. NMDA and beta1-adrenergic receptors differentially signal phosphorylation of glutamate receptor type 1 in area CA1 of hippocampus. J Neurosci 23: 5827-5834.

Waskiewicz AJ, Johnson JC, Penn B, Mahalingam M, Kimball SR, Cooper JA. 1999. Phosphorylation of the cap-binding protein eukaryotic

translation initiation factor 4E by protein kinase Mnk1 in vivo. Mol Cell Biol 19: $1871-1880$
Williams JM, Mason-Parker SE, Abraham WC, Tate WP. 1998. Biphasic changes in the levels of $N$-methyl-D-aspartate receptor-2 subunits correlate with the induction and persistence of long-term potentiation. Mol Brain Res 60: 21-27.

Williams JM, Guévremont D, Mason-Parker SE, Luxmanan C, Tate WP, Abraham WC. 2007. Differential trafficking of AMPA and NMDA receptors during long-term potentiation in awake adult animals. $J$ Neurosci 27: 14171-14178.

Winder DG, Martin KC, Muzzio IA, Rohrer D, Chruscinski A, Kobilka B, Kandel ER. 1999. ERK plays a regulatory role in induction of LTP by theta frequency stimulation and its modulation by beta-adrenergic receptors. Neuron 24: 715-726.

Woo NH, Nguyen PV. 2003. Protein synthesis is required for synaptic immunity to depotentiation. J Neurosci 23: 1125-1132.

Received August 5, 2010; accepted in revised form September 28, 2010. 


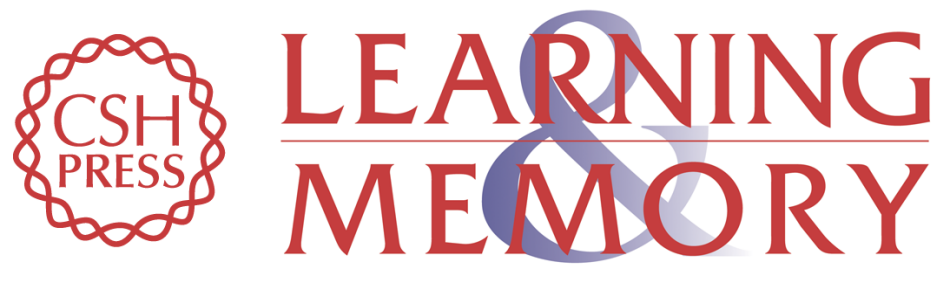

\section{'Silent' priming of translation-dependent LTP by $\beta$-adrenergic receptors involves phosphorylation and recruitment of AMPA receptors}

Gustavo Tenorio, Steven A. Connor, Diane Guévremont, et al.

Learn. Mem. 2010, 17:

Access the most recent version at doi:10.1101/lm.1974510

References This article cites 65 articles, 25 of which can be accessed free at: http://learnmem.cshlp.org/content/17/12/627.full.html\#ref-list-1

License

Email Alerting

Receive free email alerts when new articles cite this article - sign up in the box at the Service top right corner of the article or click here. 